\title{
The effects of two different anesthesia and analgesia techniques on NK cell cytotoxicity in patients undergoing surgery for colorectal cancer
}

\author{
ISADORA ZAHARESCU ${ }^{1,4}$, GHEORGHIT,A ISVORANU ${ }^{2}$, RUSU ELENA ${ }^{3}$, \\ COSMIN MOLDOVAN ${ }^{3}$, CRISTIANA TANASE ${ }^{2,3}$
}

\footnotetext{
${ }^{1}$ Titu Maiorescu University of Bucharest, Medicine Doctoral School, Bucharest, Romania

${ }^{2}$ Victor Babes National Institute of Pathology, 99-101 Splaiul Independentei, 050096, Biochemistry-Proteomics Department 050096, Bucharest, Romania

${ }^{3}$ Titu Maiorescu University of Bucharest, Faculty of Medicine, 004051, Bucharest, Romania

${ }^{4}$ Witting Clinical Hospital, Intensive Care Unit, Bucharest, Romania
}

\begin{abstract}
Perioperative anesthesia and analgesia may contribute in emphasizing immunosuppression in cancer patients. The natural killer (NK) cells play an important role in anti-tumor immunity. The aim of this study was to evaluate the effects of two different techniques of anesthesia and analgesia on the immune function by NK cell cytotoxicity (NKCC \%) in surgical patients for elective colorectal cancer surgery. Thirty-three patients operated for colorectal cancer with resection were selected to receive general anesthesia with postoperative opioids and non-steroid anti-inflammatory drugs (NSAID), the GA group, or general anesthesia combined with epidural anesthesia and analgesia, the GAE Group. NKCC (\%) for immune modulation was determined before and $24 \mathrm{~h}$ after surgery. Preoperative values NKCC $(\%)$ were found to be similar between the two groups (16.43 in the GA group vs. 16.65 in the GAE group). A decrease of NKCC \% was recorded at $24 \mathrm{~h}$ after surgery in both groups: from $16.43+/-1.8$ to $11.94+/-1.3(\mathrm{p}<0.05)$ in the GA group and from $16.66+/-1.4$ to $14.52+/-1.2$ in the GAE group. Analysis of the individual decrease expression revealed a decline by $24 \%$ the GA group compared with $12 \%$ in the GAE group $(p=0.007)$. Combined general anesthesia with epidural analgesia is superior to general anesthesia alone in regards of preserving the NK cell cytoxicity, thus delivering a lower impact on immune function for patients with elective colorectal surgery.
\end{abstract}

Keywords Anesthesia, analgesia, NK cell, cytotoxicity, colorectal cancer.

To cite this article: ZAHARESCU I, ISVORANU G, ELENA R, MOLDOVAN C, TANASE $C$. The effects of two different anesthesia and analgesia techniques on NK cell cytotoxicity in patients undergoing surgery for colorectal cancer. Rom Biotechnol Lett. 2020; 25(2): $1482-1487$. DOI: $10.25083 / \mathrm{rbl} / 25.2 / 1482.1487$ 


\section{Introduction}

For many malignant tumors, surgical resection is the mainstay treatment, but surgery itself can promote the development of metastasis by releasing tumor cells into circulation, augmenting angiogenesis or suppressing the cellular immune system (ZAHARESCU et al, 2017 [1]).

Natural killer (NK) cells are a critical component of the anti-tumor immune response, they play a major role in innate and adaptive immunity (ISVORANU, 2017 [2]). Their main function is recognition and killing of virusinfected cells or tumor cells. There are very-well documented studies that report a significant alteration of NK cell functions in cancer (SHAKHAR and BLUMENFELD, 2003 [3], ISVORANU, 2015 [4], ISVORANU, SURCEL et al, 2019 [5]). The immune system is suppressed by surgery, which promotes inflammation (VOGELAAR, LIPS et al, 2016 [6]). Also, antitumor immune potential can have a significant impact on postoperative outcomes in cancer patients. Animal models and retrospective clinical data suggest an association between anesthetic and analgesic techniques and cancer recurrence or metastasis. Postoperative suppression of the immune response may affect the tumor metastases disseminated after surgery (SALO, 1992 [7]). Stress response after surgery leads to depression of natural killer (NK) cell functions which is associated with increased tumor growth and metastasis in animal models (BEN-ELIYAHU, PAGE et al, 1999 [8]).

Opioids are a common first-choice analgesic for postoperative pain management, but there is an emerging interest in the possible association between perioperative use of opioids and recurrence or metastasis after cancer surgery. Immunomodulation induced by opioids occurs through direct action on immune cells (AL-HASHIMI, SCOTT et al, 2013 [9]). There is evidence that indicates Fentanyl of suppressing postoperative NK cell function both in patients and animal studies, which may increase the risk of tumor metastasis (SHAVIT, BEN-ELIYAHU et al, 2004 [10], FORGET, COLLET et al, 2010 [11]). An increased risk of cancer recurrence after radical prostatectomy was associated with postoperative opioid analgesia when is compared with epidural analgesia (BIKI, MASCHA et al, 2008 [12]). To avoid the immunosuppressive effects of opioids in cancer patients undergoing surgery an alternative choice is the use of non-opioid analgesic techniques (KIM, KIM et al, 2016 [13]).

The goal of this study was to compare the impact of two different anesthesia techniques - General Anesthesia (GA) and combined General Anesthesia with Epidural Anesthesia (GAE) - on the status of the immune function, assessed by the NK cell cytotoxicity (NKCC \%), in patients for elective colorectal cancer surgery.

\section{Material and Methods}

Our study is a prospective clinical study conducted in the Intensive Care Unit and General Surgery Ward of Witting Clinical Hospital Bucharest, Romania, from January 2015 to August 2018. The design of the study and the patient enrollment protocol was approved by the internal Ethics Committee of Witting Clinical Hospital, Bucharest, Romania, also a written informed consent was obtained.

Forty-five patients were enrolled, undergoing colorectal surgery with tumor resection; 33 completed the study. Patients with American Society of Anesthesiology (ASA) physical status I-III were randomized into two groups to receive either general anesthesia $(\mathrm{GA}, \mathrm{n}=16)$ or general anesthesia combined with epidural anesthesia/analgesia (GAE, n=17). GA Group received general anesthesia (opioids - Sevoflurane) with postoperative opioids - NSAIDs analgesia and GAE Group received a combined anesthesiageneral anesthesia and epidural anesthesia/postoperative analgesia.

The postoperative pain scores were assessed using a visual analogue scale (VAS) and the use of perioperative opioids were also evaluated.

Anesthesia was maintained in the GA group with Sevoflurane 1.5-2 \% to maintain BIS values of 40-60 and Fentanyl $1 \mu \mathrm{g} / \mathrm{kg}$ was added intraoperatively as required; meanwhile in the GAE group we used Sevoflurane $<1.5 \%$ with the addition of epidural anesthesia which was maintained with the use of $1 \%$ Ropivacaine during surgery. Postoperative analgesia consisted in a multimodal approach (opioids + NSAIDs) for the GA group while for the GAE group we used the epidural analgesia (infusion of Ropivacaine $0.2-0.3 \%$ and $5 \mu \mathrm{g} / \mathrm{ml}$ Fentanyl).

Blood samples were obtained to determine NKCC (\%) at the following moments: $\mathrm{T} 1$, before the induction of anesthesia and $\mathrm{T} 2$ at 24 hours after surgery.

\section{Isolation and cryopreservation of peripheral blood mononuclear cells (PBMC)}

PBMC were isolated by ficoll gradient centrifugation from heparinized blood. After whole blood was mixed with the same volume of Roswell Park Memorial Institute (RPMI) 1640 medium (Gibco, Invitrogen, CO), it was laid on a Biocoll separating solution density $1.077 \mathrm{~g} / \mathrm{ml}$ (Biochrom, GmbH) and centrifuged at $2000 \mathrm{rpm}$ for 20 minutes. After the centrifugation, the layer of PBMC was harvested and washed twice with RPMI 1640 and resuspended in culture media that contained $20 \%$ dimethyl sulfoxide (DMSO). For cryopreservation, PBMC were aliquoted at a concentration of $1 \times 10^{7}$ cells per cryogenic vial. The cells were placed in a $-80^{\circ} \mathrm{C}$ freezer for 24 hours and then transferred into a liquid nitrogen freezer until 
use. The PBMC were used within 2 months of the date they were frozen. Frozen PBMC were thawed in a $37^{\circ} \mathrm{C}$ water bath until a small amount of frozen material was left, then washed in complete media. After that the cells were incubated overnight at $37^{\circ} \mathrm{C}$ in $5 \% \mathrm{CO} 2$ atmosphere.

\section{NK cell cytotoxicity assay}

NK cell cytotoxicity was assessed with the CytoTox 96 Non-Radioactive Cytotoxicity Assay (Promega Co., WI) using K562 cells as a target cell line. By this colorimetric assay lactate dehydrogenase (LDH), a cytosolic enzyme that is released upon cell lysis, is quantitatively measures. Peripheral blood mononuclear cells $\left(2 \times 10^{5}\right.$ cells/well; effector cell, E) were mixed with K562 cells $\left(2 \times 10^{4}\right.$ cells/well; targeted cell, T) were mixed in a 96 -well and incubated at $37^{\circ} \mathrm{C}$ with $5 \% \mathrm{CO} 2$ for 4 hours. The NK cell cytotoxicity of effector cells was measured at $490 \mathrm{~nm}$ (Absorbance Microplate Reader Sunrise-Basic Tecan, Grödig, Austria) and was calculated using the following equation:

NKCC $\%=($ Experimental - Effector Spontaneous - Target Spontaneous) / (Target Maximum - Target Spontaneous) x 100

where "Experimental" is the experimental LDH release of co-cultured effector and target cells, "Effector Spontaneous" and "Target Spontaneous" express the spontaneous released LDH of the effector and target

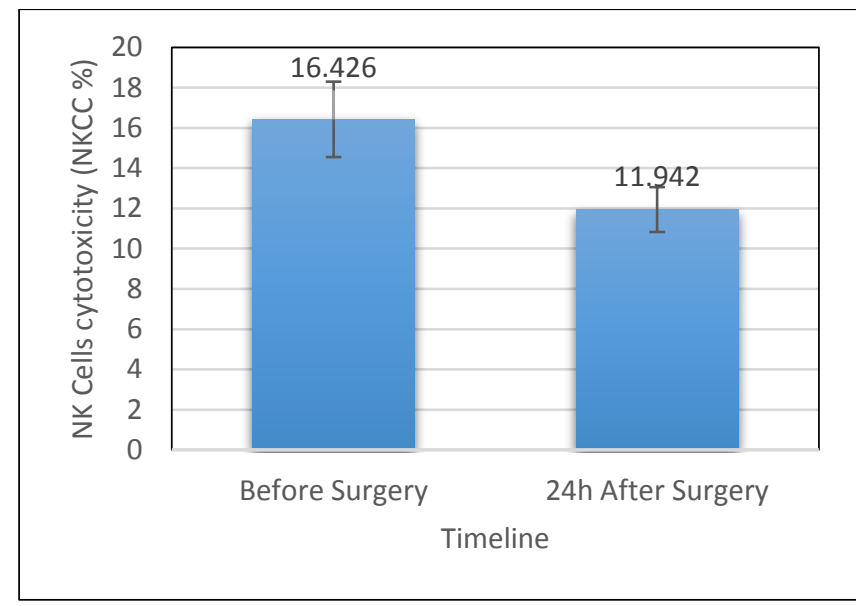

Figure 1. NKCC (\%) evolution at 24 hours postoperatively at GA group, a decrease with $24 \%$ was observed ( $\mathrm{p}=0.048)$. cells alone, respectively, and "Target Maximum" is the maximum $\mathrm{LDH}$ release of target cells.

Collected data was introduced in a local database using the Microsoft Excel Office software. The statistical analysis was performed using the SPSS v16.0 software (SPSS Inc. Chicago, IL, USA) and was presented as mean \pm standard error (SEM). For statistical analysis, the Student t-test (two-tailed, assuming equal variance) was used for statistical evaluation of the differences. The difference between the individual decreases of the NKCC\% between the two groups was analyzed for statistical relevance. The results were considered significant when $p$ values were $<0.05$.

\section{Results}

There were no significant differences in terms of patient characteristics and surgical factors between the two groups.

Before surgery (T1), the quantitative values of the Natural Killer (NK) cells cytotoxicity (NKCC \%) are similar in both groups: $16.43 \%$ in the GA group vs. $16.65 \%$ in the GAE group.

At T2 (24 h after surgery), we found a decrease of NKCC (\%) in both groups: in GA group NKCC (\%) decreased from $16.43+/-1.87$ to $11.94+/-1.11(\mathrm{p}=0.048)$ and in GAE group from $16.65+/-1.41$ to $14.52+/-1.19$, with a statistical significance in GA group (Figure 1 and 2).

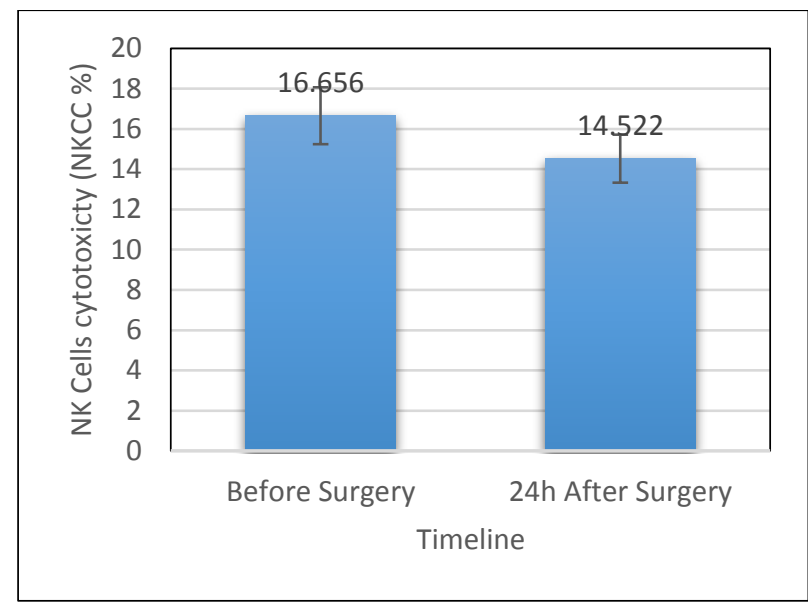

Figure 2. NKCC (\%) evolution at 24 hours at GAE group, a decrease of $12 \%$.

This comparative analysis of individual decreases revealed a statistical relevant value $(\mathrm{p}=0.007)$ (Figure 4$)$.

The evolution of NKCC depending on the operative times and type of anesthesia revealed that a lower decrease of NKCC in patients who were given combined anesthesia than those who were given only general anesthesia. 


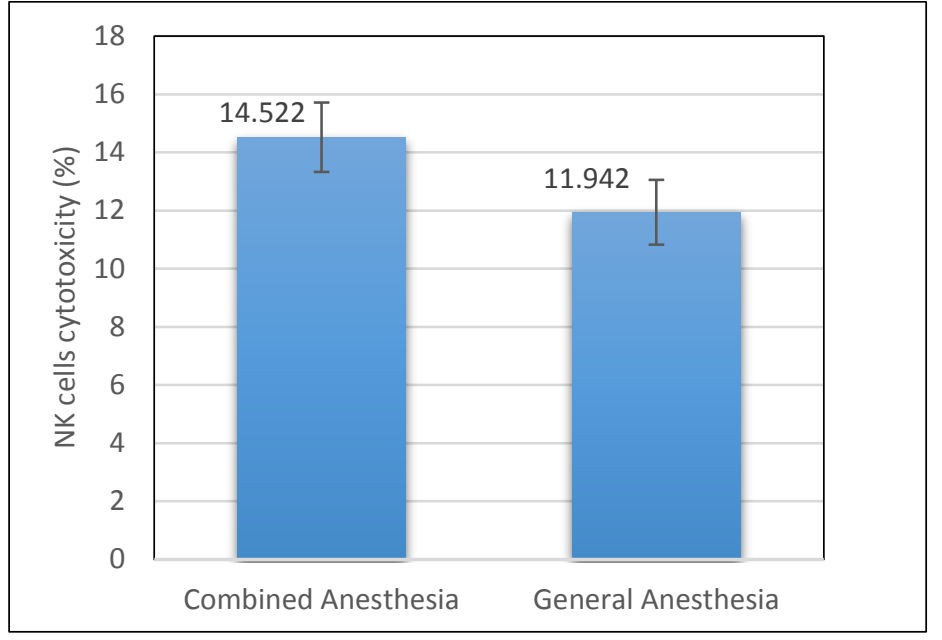

Figure 3. Comparison of the levels of the NKCC\% at $24 \mathrm{~h}$ after surgery between the two groups.

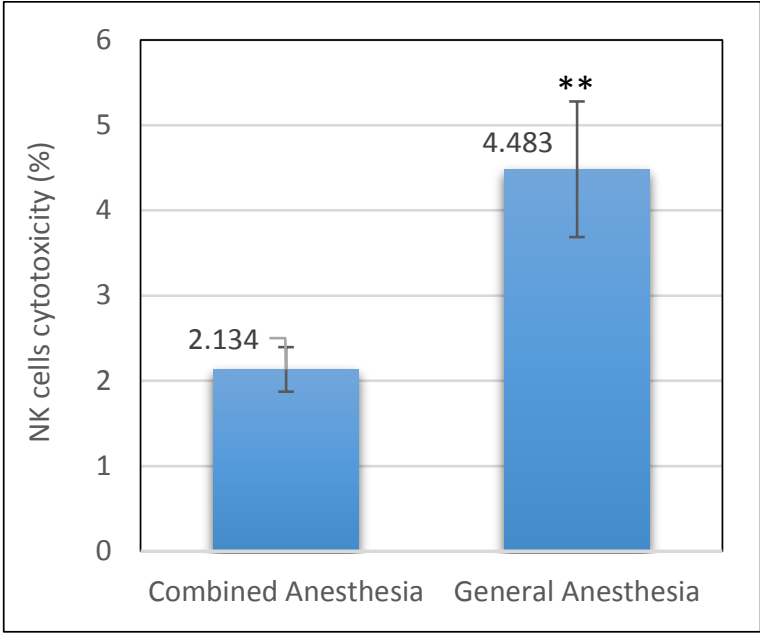

Figure 4. Comparison of the differences of NKCC\% (preoperatively versus postoperative) between the two groups $(\mathrm{p}=0.007)$.

\section{Discussions}

The immune system of patients during the perioperative period can be affected directly or indirectly by anesthesia and other related drugs and thus can affect treatment and prognosis of colorectal cancer patients. The effects of anesthesia on immunity have been studied on multiple factors, including NK cells, B-lymphocytes, T-lymphocytes, macrophages, leukocytes and some cytokines (TNF- $\alpha$, IL-1, IL-6, IL-8, IL-10, IFN, IFN-7, soluble Interleukin-2 receptor (sIL-2R) (ZAHARESCU, MOLDOVAN et al, 2017 [1]).

In our study, the cytotoxic capacity of natural killer cells (NKCC \%) registered a decrease at $24 \mathrm{~h}$ after surgery in both groups with statistically significant correlation in GA group. Between the two moments T2-T1, NKCC\% shows a drop rate more pronounced in GA group with $24 \%$ compared with GAE group, with $12 \%$ ( $p=0.007$ ).

Therefore, we note that patients who received only general anesthesia and postoperative analgesia with opioids + NSAIDs systemically developed a significant reduction in the cytotoxic capacity of NK cells compared to those who received combined general anesthesia with postoperative epidural analgesia, proving the favorable effects of combined anesthesia.

There is quite a challenge to study in a comparative manner the effects of different anesthesia methods on perioperative immunity in patients with cancers, the results of available studies showing that the degree of impairment of immunosuppression varies depending on the type of anesthesia.

These findings can be partially explained by the stress induced by surgery, which inhibits the activity of NK cells responsible for lysis of tumor cells and promotes the stimulation of pro-angiogenic factors. Perioperative immunosuppression can be attributed to activation of the sympathetic nervous system and the hypothalamic- pituitary axis. Catecholamine released from sympathetic nervous system activation bind to NK cell adrenoceptors, $\mathrm{T}$ lymphocytes, and macrophages leading to inhibition of NK cell activity and stimulation of LTh2 production by increasing balance in their favor (KUROSAWA, 2012 [14], DIVATIA and AMBULKAR, 2014 [15]).

Animal experiments show that tumor growth is associated with impaired cytotoxic capacity of NK cells, counteracted by beta-blockers and NSAIDs (PANTZIARKA, BOUCHE et al, 2016 [16]).

On human subjects, Kwon et al. (KWON, KWON et al, 2015 [17]) demonstrated a reduction in the cytotoxic capacity of NK cells for 3 months postoperatively in patients with hepatocellular cancer and Crane et al. demonstrated that the resumption of the cytotoxic function of NK cells in patients with glioblastoma was associated with increased expression of NKG2D receptors and reduced circulating MHC Class I Polypeptide-Related Sequence A (MICA) values (CRANE, HAN et al 2010 [18]).

Cata J.P. found that NK cell count in the perioperative period seem to have a biphasic response: increased number of circulating NK cells intraoperatively and minutes after surgery, effect mediated by epinephrine acting on $\beta 2$-adrenergic receptors, followed by a sustained drop for several days up to a month in stage II or III of colorectal cancer surgery. However the study does not mention anything about the $\mathrm{NKCC}(\%)$ (CATA, CONRAD et al, 2015 [19]).

A link between the number and function of NK cells, on one hand and prognosis the other hand was found in patients with solid tumors (ANGKA, KHAN et al, 2017 [20]). Some studies in solid tumors have shown that NK-CD8+ cell association is related to a better prognosis compared with NK-CD3+-CD4+ cell association, suggesting an intratumor interdependence between NK cells and CD8+ lymphocytes (SCONOCCHIA, EPPENBERGER et al, 2014 [21], Donadon, HUDSPETH et al, 2017 [22]). In colorectal cancers, the presence of intra-tumor NK cells 
has been associated with a better prognosis. These cells can exert a protection against cancer-initiating cells, cells with greater resistance to anti-tumor treatment but are more sensitive to NK cells. Therefore increasing the NKCC might contribute to reducing the risk of recurrence (PERNOT, TERME et al, 2014 [23]).

Regarding the comparison of NKCC in two types of anesthesia (general anesthesia versus combined general anesthesia with regional anesthesia) our results are in accordance with other studies conducted so far. Wada et al demonstrated in animal models that epidural or spinal blockade results in a reduction of the immune suppression after surgery and protection against postoperative metastasis (WADA, SEKI et al, 2007 [24]).

Exadaktylos et al studied 129 cases of mastectomy for primary breast cancer and found lower cancer recurrence and metastasis 2.5 years after surgery in patients that received paravertebral anesthesia with general anesthesia compared to those that had received general anesthesia alone $(\mathrm{p}=0.012)$ (EXADAKTYLOS, BUGGY et al, 2006 [25]).

Biki et al showed that in radical prostatectomy, using epidural anesthesia and analgesia was associated with a lower risk of biochemical cancer recurrence $(57 \%, \mathrm{p}=0,012)$ (BIKI, MASCHA et al, 2008 [12]).

Christopherson et al demonstrated that epidural supplementation was associated with enhanced survival of patients without metastases before 1.46 years $(\mathrm{p}=0,012)$ (CHRISTOPHERSON, JAMES et al, 2008 [26]).

Lusty et al advocate for the beneficial roles of regional anesthesia in urological surgery, with an improvement of the oncological and immunological responses after surgery potentially through a decreased use of opioids and the direct anti-inflammatory effect of the local anesthetics (LUSTY, HOSIER et al, 2019 [27]).

Regarding the influence of opioids on the activity of NK cells, Wodehouse et al. found the superiority of non-opioid epidural analgesia at clinical dose compared with Morphine by preserving the activity of NK cells (WODEHOUSE, DEMOPOULOS et al, 2019 [28]). In our study, the use of Ropivacaine, a non-opioid epidural analgesia, which may partially explain the trend of the NKCC in the GAE group.

Wang et al. suggest that a combination technique of anesthesia may attenuate the intraoperative stress response and postoperative pain in patients undergoing radical esophagectomy (WANG, YIN et al, 2019 [29]).

However, other studies failed to show any benefits for regional anesthesia/analgesia regarding recurrence and mortality rate after surgery for colorectal, cervical cancers and prostate cancer, even though it reduced the need for postoperative systemic opioid administration (GOTTSCHALK, FORD et al, 2010 [30]), (ISMAIL, HO et al, 2010 [31]).

Regarding the NK cell evaluation in patients with pulmonary carcinoma, Chen J. et al, showed at $24 \mathrm{~h}$ after surgery that NK cells values were decreased in both groups, with immunological function recovered in the epidural technique group at $72 \mathrm{~h}$ after surgery $(\mathrm{p}<0.05)$ (CHEN, LUO et al, 2017).
Contrary to the above, Gao H. stated the better effects of general anesthesia on survival rates in colorectal cancers with liver metastases, underlining the importance of cancer type in analyzing the effects of anesthetic techniques (GAO, MENG et al, 2019 [32]).

Still, there is an increasing interest in the opioid-free anesthesia in cancer patients, a procedure known for its effects on tumor cells, but is under debate (MALOMANSO, RAIGON-PONFERRADA et al, 2019 [33]).

\section{Conclusions}

Our study reveals that combined general anesthesia with postoperative epidural analgesia demonstrated a favorable impact on immune function by preserving $\mathrm{NK}$ cells cytotoxicity compared with general anesthesia and postoperative opioids analgesia in patients undergoing colorectal cancer surgery.

\section{Acknowledgements}

This material is part of a $\mathrm{PhD}$ thesis of Izadora Zaharescu, MD, PhD Student. The authors acknowledge Incze (Kutasi) Réka for her invaluable support in language proofing the final manuscript in English. This study was partially funded by a research grant with ID: PR03 internal research grant, Titu Maiorescu University, Romania.

\section{References}

1. ZAHARESCU I, MOLDOVAN AD and TANASE C. "Natural killer (NK) cells and their involvement in different types of cancer. Current status of clinical research." Journal of Mind and Medical Sciences 4(1): 31-37 (2017).

2. ISVORANU G. "The Memory Activation of NK Cells - New Methods in Cancer Immunotherapy. Immunotherapy - Myths, Reality, Ideas, Future." IntechOpen: 201-219 (2017).

3. SHAKHAR G and BLUMENFELD B. "Glucocorticoid involvement in suppression of NK activity following surgery in rats." $J$ Neuroimmunol 138(1-2): 83-91 (2003).

4. ISVORANU G. "Immunotherapy in cancer - in vivo study of the anti-tumor activity of the IL-15/IL-15R alfa combination in an experimental model of melanoma." Farmacia 5(63): 631-636 (2015).

5. ISVORANU G, SURCEL M, HUICA RI, MUNTEANU AN, PIRVU IR, CIOTARU D, CONSTANTIN C, BRATU O, NEAGU M, URSACIUC C. "Natural killer cell monitoring in cutaneous melanoma - new dynamic biomarker.” Oncol Lett 17(5): 4197-4206 (2019).

6. VOGELAAR FJ, LIPS DJ, VAN DORSTEN FR, LEMMENS VE, BOSSCHA K. "Impact of anaesthetic technique on survival in colon cancer: a review of the literature." Gastroenterol Rep (Oxf) 4(1): 30-34 (2016).

7. SALO M. "Effects of anaesthesia and surgery on the immune response." Acta Anaesthesiol Scand 36(3): 201-220 (1992).

8. BEN-ELIYAHU S, PAGE GG, YIRMIYA R, SHAKHAR G. "Evidence that stress and surgical interventions promote tumor development by suppressing natural killer cell activity." Int J Cancer 80(6): 880-888 (1999). 
9. AL-HASHIMI M, SCOTT SW, THOMPSON JP LAMBERT DG. "Opioids and immune modulation: more questions than answers." Br J Anaesth 111(1): 80-88 (2013).

10. SHAVIT Y, BEN-ELIYAHU S, ZEIDEL A, BEILIN B. "Effects of fentanyl on natural killer cell activity and on resistance to tumor metastasis in rats. Dose and timing study." Neuroimmunomodulation 11(4): 255-260 (2004).

11. FORGET P, COLLET V, LAVAND'HOMME P, DE KOCK M. "Does analgesia and condition influence immunity after surgery? Effects of fentanyl, ketamine and clonidine on natural killer activity at different ages." Eur J Anaesthesiol 27(3): 233-240 (2010).

12. BIKI B, MASCHA E, MORIARTY DC, FITZPATRICK JM, SESSLER DI, BUGGY DJ. "Anesthetic technique for radical prostatectomy surgery affects cancer recurrence: a retrospective analysis." Anesthesiology 109(2): 180-187 (2008).

13. KIM SY, KIM NK, BAIK SH, MIN BS, HUR H, LEE J, NOH HY, LEE J.H, KOO BN. "Effects of Postoperative Pain Management on Immune Function After Laparoscopic Resection of Colorectal Cancer: A Randomized Study." Medicine (Baltimore) 95(19): e3602 (2016)

14. KUROSAWA S. "Anesthesia in patients with cancer disorders." Curr Opin Anaesthesiol 25(3): 376-384 (2012).

15. DIVATIA JV and AMBULKAR R. "Anesthesia and cancer recurrence: What is the evidence?" J Anaesthesiol Clin Pharmacol 30(2): 147-150 (2014).

16. PANTZIARKA P, BOUCHE G, SUKHATME V, MEHEUS L, ROOMAN I, SUKHATME VP. "Repurposing Drugs in Oncology (ReDO)-Propranolol as an anticancer agent." Ecancermedicalscience 10: 680 (2016).

17. KWON HJ, KWON SJ, LEE H, PARK HR, CHOI GE, KANG SW, KWON SW, KIM N, LEE SY, RYU S, KIM SC, KIM HS. "NK cell function triggered by multiple activating receptors is negatively regulated by glycogen synthase kinase-3beta." Cell Signal 27(9): 1731-1741 (2015).

18. CRANE CA, HAN SJ, BARRY JJ, AHN BJ, LANIER LL, PARSA AT. "TGF-beta downregulates the activating receptor NKG2D on NK cells and CD8+ T cells in glioma patients." Neuro Oncol 12(1): 7-13 (2010).

19. CATA JP, CONRAD C, REZVANI K. "Potential Use of Natural Killer Cell Transfer Therapy in the Perioperative Period to Improve Oncologic Outcomes." Scientifica (Cairo) 2015: 732438 (2015).

20. ANGKA L, KHAN ST, KILGOUR MK, XU R, KENNEDY MA, AUER RC. "Dysfunctional Natural Killer Cells in the Aftermath of Cancer Surgery." Int J Mol Sci 18(8) (2017).

21. SCONOCCHIA G, EPPENBERGER S, SPAGNOLI GC, TORNILLO L, DROESER R, CARATELLI S, FERRELLI F, COPPOLA A, ARRIGA R, LAURO D, IEZZI G, TERRACCIANO L, FERRONE S. "NK cells and $\mathrm{T}$ cells cooperate during the clinical course of colorectal cancer." Oncoimmunology 3(8): e952197 (2014).

22. DONADON M, HUDSPETH K, CIMINO M, DI TOMMASO L, PRETI $M$, TENTORIO $\mathrm{P}$,
RONCALLI M, MAVILIO D, TORZILLI G. "Increased Infiltration of Natural Killer and T Cells in Colorectal Liver Metastases Improves Patient Overall Survival." J Gastrointest Surg 21(8): 1226-1236 (2017).

23. PERNOT S, TERME M, VORON T, COLUSSI O, MARCHETEAU E, TARTOUR E, TAIEB J. "Colorectal cancer and immunity: what we know and perspectives." World J Gastroenterol 20(14): 3738-3750 (2014)

24. WADA H, SEKI S, TAKAHASHI T, KAWARABAYASHI N, HIGUCHI H, HABU Y, SUGAHARA S, KAZAMA T. "Combined spinal and general anesthesia attenuates liver metastasis by preserving TH1/TH2 cytokine balance." Anesthesiology 106(3): 499-506 (2007).

25. EXADAKTYLOS AK, BUGGY DJ, MORIARTY DC, MASCHA E, SESSLER DI. "Can anesthetic technique for primary breast cancer surgery affect recurrence or metastasis?" Anesthesiology 105(4): 660664 (2006)

26. CHRISTOPHERSON R, JAMES KE, TABLEMAN M, MARSHALL P, JOHNSON FE. "Long-term survival after colon cancer surgery: a variation associated with choice of anesthesia." Anesth Analg 107(1): 325-332 (2008).

27. LUSTY AJ, HOSIER GW, KOTI M, CHENARD S, MIZUBUTI GB, JAEGER M, SIEMENS DR. "Anesthetic technique and oncological outcomes in urology: A clinical practice review." Urol Oncol 37(12): 845-852 (2019).

28. WODEHOUSE T, DEMOPOULOS M, PETTY R, MIRAKI-MOUD F, BELHAJ A, HUSBAND M, FULTON L, RANDIVE N, OKSCHE A, MEHTA V, GRIBBEN J, LANGFORD R. "A randomized pilot study to investigate the effect of opioids on immunomarkers using gene expression profiling during surgery." Pain 160(12): 2691-2698 (2019).

29. WANG J, YIN Y, ZHU Y, XU P, SUN Z, MIAO C, ZHONG J. "Thoracic epidural anaesthesia and analgesia ameliorates surgery-induced stress response and postoperative pain in patients undergoing radical oesophagectomy." J Int Med Res 47(12): 6160-6170 (2019).

30. GOTTSCHALK A, FORD JG, REGELIN CC, YOU J, MASCHA EJ, SESSLER DI, DURIEUX M.E. and NEMERGUT EC. "Association between epidural analgesia and cancer recurrence after colorectal cancer surgery." Anesthesiology 113(1): 27-34 (2010).

31. ISMAIL H, HO KM, NARAYAN K, KONDALSAMYCHENNAKESAVAN S. "Effect of neuraxial anaesthesia on tumour progression in cervical cancer patients treated with brachytherapy: a retrospective cohort study." Br J Anaesth 105(2): 145-149 (2010).

32. GAO H, MENG XY, WANG HQ, ZHU FF, GUO AL, ZHU M, SONG JC, YU WF. "Association between Anaesthetic Technique and Oncological Outcomes after Colorectal Carcinoma Liver Metastasis Resection." Int J Med Sci 16(2): 337-342 (2019).

33. MALO-MANSO A, RAIGON-PONFERRADA A, DIAZ-CRESPO J, ESCALONA-BELMONTE JJ, CRUZ-MANAS J, GUERRERO-ORRIACH JL. "Opioid Free Anaesthesia and Cancer." Curr Pharm Des 25(28): 3011-3019 (2019). 